\title{
Solution of a Variational inequality Problem for Accretive Operators in Banach Spaces
}

\author{
${ }^{1}$ Renu Chugh and ${ }^{2}$ Rekha Rani* \\ ${ }^{I}$ Department of Mathematics, Maharshi Dayanand University, Rohtak (INDIA). \\ ${ }^{2}$ Department of Mathematics, A. I. J. H. M. College, Rohtak (INDIA)
}

*rekhadala193@gmail.com

\begin{abstract}
This paper introduces a two-step iterative process for finding a solution of a variational inequality problem for accretive operators in Banach spaces. The result obtained in this paper is motivated by the result given by Koji Aoyama et al [3]. Further, we consider the problem of finding a fixed point of a strictly pseudocontractive mapping in a Banach space.
\end{abstract}

Keywords: Accretive operators, sunny non-expansive retractions, Banach spaces, variational inequality problem.

\section{Introduction}

Let $\mathrm{E}$ be any smooth Banach space with II. II. Let $\mathrm{E}^{*}$ denote the dual of $\mathrm{E}$ and $\langle\mathrm{x}, \mathrm{f}\rangle$ denote the value of $f \in E^{*}$ at $x \in E$. Let $C$ be a nonempty closed convex subset of $E$ and let $A$ be an accretive operator of $C$ into $E$. The generalized variational inequality problem in Banach space is to find an element $\mathrm{u} \in \mathrm{C}$ such that $<A u, J(v-u)>\geq 0 \forall v \in C$, where $J$ is the duality mapping of $E$ into $E^{*}$.

Definiton 1.1 A Banach space $\mathrm{E}$ is called uniformly convex iff for any $\varepsilon, 0<\varepsilon \leq 2$, the inequalities $\|\mathrm{x}\| \leq 1$, $\|\mathrm{y}\| \leq 1$ and $\|\mathrm{x}-\mathrm{y}\| \geq \varepsilon$ imply there exists a $\delta>0$ such that $\left\|\frac{x+y}{2}\right\| \leq 1-\delta$.

Definition 1.2 Let $\mathrm{E}$ be any smooth Banach space. Then a function $\rho_{E}: \mathrm{R}^{+} \rightarrow \mathrm{R}^{+}$is said to be modulus of smoothness of $\mathrm{E}$ if

$$
\rho_{E}(\mathrm{t})=\sup \left\{\frac{\|x+y\|+\|x-y\|}{2}-1 ;\|x\|=1,\|y\|=t\right\} .
$$

Definition 1.3 A Banach space E is said to be uniformly smooth if

$$
\lim _{t \rightarrow 0} \frac{\rho_{E}(t)}{t}=0
$$

Remark 1.4 Let $\mathrm{q}>1$. A Banach space $\mathrm{E}$ is said to be q-uniformly smooth if there exists a fixed constant $\mathrm{c}>0$ such that $\rho_{E}(\mathrm{t})=\mathrm{ct}^{\mathrm{q}}$ for all $\mathrm{t}>0$. For more details, see [4,11]. It is obvious that if $\mathrm{E}$ is q-uniformly smooth, then $\mathrm{q} \leq 2$ and $\mathrm{E}$ is uniformly smooth.

Definition 1.5 Let $\mathrm{J}$ be any mapping from $\mathrm{E}$ into $\mathrm{E}^{*}$ satisfying $\mathrm{J}(\mathrm{x})=\left\{\mathrm{f} \varepsilon \mathrm{E}^{*}:\left\langle\mathrm{x}, \mathrm{f}>=\|\mathrm{x}\|^{2}\right.\right.$ and $\left.\|\mathrm{f}\|=\|\mathrm{x}\|\right\}$. Then $\mathrm{J}$ is called the normalized duality mapping of $\mathrm{E}$.

Definition 1.6 Let $\mathrm{C}$ be a non-empty subset of a Banach space $\mathrm{E}$. A mapping $\mathrm{T}: \mathrm{C} \rightarrow \mathrm{C}$ is called nonexpansive [10] if

$\|\mathrm{Tx}-\mathrm{Ty}\|=\|\mathrm{x}-\mathrm{y}\| \quad \forall \mathrm{x}, \mathrm{y} \varepsilon \mathrm{C}$.

T is called $\eta$-strictly pseudo-contractive if there exists a constant $\eta \varepsilon(0,1)$ such that

$<\mathrm{Tx}-\mathrm{Ty}, \mathrm{j}(\mathrm{x}-\mathrm{y})>\leq\|\mathrm{x}-\mathrm{y}\|^{2}-\eta\|(\mathrm{I}-\mathrm{T}) \mathrm{x}-(\mathrm{I}-\mathrm{T}) \mathrm{y}\|^{2}$

for every $\mathrm{x}, \mathrm{y} \varepsilon \mathrm{C}$ and for some $\mathrm{j}(\mathrm{x}-\mathrm{y}) \varepsilon \mathrm{J}(\mathrm{x}-\mathrm{y})$.

It is obvious that $(1.1)$ is equivalent to

$<(\mathrm{I}-\mathrm{T}) \mathrm{x}-(\mathrm{I}-\mathrm{T}) \mathrm{y}, \mathrm{j}(\mathrm{x}-\mathrm{y})>\geq \eta\|(\mathrm{I}-\mathrm{T}) \mathrm{x}-(\mathrm{I}-\mathrm{T}) \mathrm{y}\|^{2}$

Definition 1.7 A Banach space $\mathrm{E}$ is said to be smooth if the limit

$\lim _{t \rightarrow 0} \frac{\|x+t y\|-\|x\|}{t}$ exists for all $\mathrm{x}, \mathrm{y} \varepsilon \mathrm{U}$, where $\mathrm{U}=\{\mathrm{x} \in \mathrm{E}:\|\mathrm{x}\|=1\}$. 
Remark 1.8 It is known that $\mathrm{J}_{\mathrm{q}}(\mathrm{x})=\|\mathrm{x}\|^{\mathrm{q}-2} \mathrm{~J}(\mathrm{x})$ for all $\mathrm{x} \varepsilon$ E. If $\mathrm{E}$ is a Hilbert space, then $\mathrm{J}=\mathrm{I}$. The normalized duality mapping $\mathrm{J}$ has the following properties:

1. If $E$ is smooth, then $J$ is single valued.

2. If $\mathrm{E}$ is strictly convex, then $\mathrm{J}$ is one-one and

$<\mathrm{x}-\mathrm{y}, \mathrm{x}^{*}-\mathrm{y}^{*}>>0$ for all $\left(\mathrm{x}, \mathrm{x}^{*}\right),\left(\mathrm{y}, \mathrm{y}^{*}\right) \varepsilon \mathrm{J}$ with $\mathrm{x} \neq \mathrm{y}$.

3. If $E$ is reflexive, then $J$ is surjective.

4. If $\mathrm{E}$ is uniformly smooth, then $\mathrm{J}$ is uniformly norm to norm continuous on each bounded subset of $\mathrm{E}$.

5. It is also known that $\mathrm{q}<\mathrm{y}-\mathrm{x}, \mathrm{j}_{\mathrm{x}}>\leq\|\mathrm{y}\|^{\mathrm{q}}-\|\mathrm{x}\|^{\mathrm{q}}$ for all $\mathrm{x}, \mathrm{y} \varepsilon E$ and $\mathrm{j}_{\mathrm{x}} \varepsilon \mathrm{J}_{\mathrm{q}}(\mathrm{x})$.

In 2006, Aoyama et al [3] obtained a weak convergence theorem.

Theorem 1.9 [3] Let E be a uniformly convex and 2-uniformly smooth Banach space with best smooth constant $\mathrm{K}$ and $\mathrm{C}$ be a nonempty closed convex subset of $\mathrm{E}$. Let $\mathrm{Q}_{\mathrm{C}}$ be a sunny nonexpansive retraction from $\mathrm{E}$ onto $\mathrm{C}, \alpha$ $>0$ and $\mathrm{A}$ be $\alpha$-inverse strongly accretive operator of $\mathrm{C}$ into $\mathrm{E}$. Let $\mathrm{S}(\mathrm{C}, \mathrm{A}) \neq \varphi$ and the sequence $\left\{\mathrm{x}_{\mathrm{n}}\right\}$ be generated by

$\mathrm{x}_{\mathrm{n}+1}=\alpha_{\mathrm{n}} \mathrm{x}_{\mathrm{n}}+\left(1-\alpha_{\mathrm{n}}\right) \mathrm{Q}_{\mathrm{C}}\left(\mathrm{x}_{\mathrm{n}}-\lambda_{\mathrm{n}} \mathrm{Ax} \mathrm{x}_{\mathrm{n}}\right), \mathrm{x}_{1} \in \mathrm{C}, \mathrm{n}=1,2,3$,

where $\left\{\lambda_{n}\right\}$ is a sequence of positive real numbers and $\left\{\alpha_{n}\right\}$ is a sequence in $[0,1]$ and $\lambda_{n} \in\left[a, \alpha / K^{2}\right]$ for some a $>0$ and let $\alpha_{\mathrm{n}} \in[\mathrm{b}, \mathrm{c}]$, where $0<\mathrm{b}<\mathrm{c}<1$, then $\left\{\mathrm{x}_{\mathrm{n}}\right\}$ converges weakly to some element $\mathrm{z}$ of $\mathrm{S}(\mathrm{C}, \mathrm{A})$.

After that for finding a common element of $\mathrm{F}(\mathrm{S}) \cap \mathrm{VI}(\mathrm{C}, \mathrm{A})$, Nadezhkina and Takahashi [5] gave another result. They obtained the following weak convergence theorem.

Theorem 1.2 [5] Let $\mathrm{C}$ be a closed convex subset of a real Hilbert space $\mathrm{H}$. Let $\mathrm{A}$ be a monotone and $\mathrm{k}$ Lipschitz continuous mapping of $\mathrm{C}$ into $\mathrm{H}$ and let $\mathrm{S}$ be a nonexpansive mapping of $\mathrm{C}$ into itself such that $\mathrm{F}(\mathrm{S})$ $\cap \operatorname{VI}(C, A) \neq \phi$. Let $\left\{x_{n}\right\},\left\{y_{n}\right\}$ be sequences generated by $\mathrm{x}_{0}=\mathrm{x} \in \mathrm{C}$, $\mathrm{y}_{\mathrm{n}}=\mathrm{P}_{\mathrm{C}}\left(\mathrm{x}_{\mathrm{n}}-\lambda_{\mathrm{n}} A \mathrm{x}_{\mathrm{n}}\right)$

$\mathrm{x}_{\mathrm{n}+1}=\alpha_{\mathrm{n}} \mathrm{x}_{\mathrm{n}}+\left(1-\alpha_{\mathrm{n}}\right) \mathrm{SP}_{\mathrm{C}}\left(\mathrm{x}_{\mathrm{n}}-\lambda_{\mathrm{n}} \mathrm{A} \mathrm{y}_{\mathrm{n}}\right), \quad \forall \mathrm{n} \geq 0$,

where $\left\{\lambda_{n}\right\} \subset[a, b]$ for some $a, b \in(0,1 / k)$ and $\left\{\alpha_{n}\right\} \subset[c, d]$ for some $c, d \in(0,1)$. Then the sequences $\left\{x_{n}\right\},\left\{y_{n}\right\}$ generated generated by (1.3) converge weakly to some $\mathrm{z} \in \mathrm{F}(\mathrm{S}) \cap \mathrm{VI}(\mathrm{C}, \mathrm{A})$.

Motivated by above results, we provide the following iterative process for an accretive operator $\mathrm{A}$ in a Banach space $\mathrm{E}$,

$\mathrm{x}_{1}=\mathrm{x} \& \mathrm{C}$

$\mathrm{y}_{\mathrm{n}}=\mathrm{Q}_{\mathrm{C}}\left(\mathrm{x}_{\mathrm{n}}-\lambda_{\mathrm{n}} \mathrm{Ax} \mathrm{x}_{\mathrm{n}}\right)$

$\mathrm{X}_{\mathrm{n}+1}=\alpha_{\mathrm{n}} \mathrm{X}_{\mathrm{n}}+\left(1-\alpha_{\mathrm{n}}\right) \mathrm{Q}_{\mathrm{C}}\left(\mathrm{y}_{\mathrm{n}}-\lambda_{\mathrm{n}} \mathrm{A} \mathrm{y}_{\mathrm{n}}\right)$, for $\mathrm{n}=1,2 \ldots \ldots \ldots \ldots$,

where $\mathrm{Q}_{\mathrm{C}}$ is sunny nonexpansive retraction from $\mathrm{E}$ onto $\mathrm{C}$. Using this iterative process, we shall obtain a weak convergence theorem.

\section{Preliminaries}

Let $\mathrm{D}$ be a subset of $\mathrm{C}$ and $\mathrm{Q}$ be a mapping from $\mathrm{C}$ to $\mathrm{D}$. Then $\mathrm{Q}$ is said to be sunny if $\mathrm{Q}(\mathrm{Qx}+\mathrm{t}(\mathrm{x}-$ $\mathrm{Qx}))=\mathrm{Qx}$, whenever $\mathrm{Qx}+\mathrm{t}(\mathrm{x}-\mathrm{Qx}) \varepsilon \mathrm{C}$ for $\mathrm{x} \varepsilon \mathrm{C}$ and $\mathrm{t} \geq 0$. A mapping $\mathrm{Q}: \mathrm{C} \rightarrow \mathrm{C}$ is called retraction if $\mathrm{Q}^{2}=$ $\mathrm{Q}$. If $\mathrm{Q}$ is any retraction, then $\mathrm{Qz}=\mathrm{z}$ for every $\mathrm{z} \varepsilon \mathrm{R}(\mathrm{Q})$, where $\mathrm{R}(\mathrm{Q})$ is the range set of $\mathrm{Q}$. A subset $\mathrm{D}$ of $\mathrm{C}$ is called a sunny nonexpansive retract of $\mathrm{C}$ if there exists a sunny nonexpansive retraction from $\mathrm{C}$ onto $\mathrm{D}$.

Now we collect some results.

Lemma 2.1 [7] Let $\mathrm{C}$ be a nonempty closed convex subset of a uniformly convex and uniformly smooth Banach space $E$ and let $T$ be a nonexpansive mapping of $C$ into itself with $F(T) \neq \varphi$. Then the set $F(T)$ is a sunny nonexpansive retract of $\mathrm{C}$.

Lemma 2.2 $[6,8]$ Let $C$ be a nonempty closed convex subset of a smooth Banach space $E$ and let $Q_{C}$ be a retraction of $\mathrm{E}$ onto $\mathrm{C}$.Then the following are equivalent

(i). $Q_{C}$ is both sunny and nonexpansive.

(ii). $<\mathrm{x}-\mathrm{Q}_{\mathrm{C}} \mathrm{X}, \mathrm{J}\left(\mathrm{y}-\mathrm{Q}_{\mathrm{C}} \mathrm{x}\right)>\leq 0$ for all $\mathrm{x} \varepsilon \mathrm{E}, \mathrm{y} \varepsilon \mathrm{C}$.

Also it is well known that if $\mathrm{E}$ is a Hilbert space, then sunny nonexpansive retraction is coincident with metric projection.

Also $\mathrm{Q}_{\mathrm{C}}$ satisfies

$\mathrm{x}_{0}=\mathrm{Q}_{\mathrm{C}} \mathrm{x}$ iff $<\mathrm{x}-\mathrm{x}_{0}, \mathrm{~J}\left(\mathrm{y}-\mathrm{x}_{0}\right)>\leq 0$ for all $\mathrm{y} \varepsilon \mathrm{C}$.

Let $\mathrm{E}$ be a Banach space and let $\mathrm{C}$ be a nonempty closed convex subset of $\mathrm{E}$. An operator $\mathrm{A}$ of $\mathrm{C}$ into $\mathrm{E}$ is said to accretive if there exists $\mathrm{j}(\mathrm{x}-\mathrm{y}) \varepsilon \mathrm{J}(\mathrm{x}-\mathrm{y})$ such that

$<A x-A y, j(x-y)>\geq 0$ for all $x, y \in C$. 
Lemma 2.3 [3] Let $C$ be a nonempty closed convex subset of a smooth Banach space E. Let $Q_{C}$ be a sunny nonexpansive retraction from $\mathrm{E}$ onto $\mathrm{C}$ and let $\mathrm{A}$ be an accretive operator of $\mathrm{C}$ into $\mathrm{E}$. Then for all $\lambda>0$,

$\mathrm{S}(\mathrm{C}, \mathrm{A})=\mathrm{F}\left(\mathrm{Q}_{\mathrm{C}}(\mathrm{I}-\lambda \mathrm{A})\right)$, where

$\mathrm{S}(\mathrm{C}, \mathrm{A})=\{\mathrm{u} \varepsilon \mathrm{C}:<\mathrm{Au}, \mathrm{J}(\mathrm{v}-\mathrm{u})>\geq 0$, for all $\mathrm{v} \varepsilon \mathrm{C}\}$.

An operator $\mathrm{A}: \mathrm{C} \rightarrow \mathrm{E}$ is said to be $\alpha$-inverse strongly accretive if

$<\mathrm{Ax}-\mathrm{Ay}, \mathrm{J}(\mathrm{x}-\mathrm{y})>\geq \alpha\|\mathrm{Ax}-\mathrm{Ay}\|^{2}$ for all $\mathrm{x}, \mathrm{y} \varepsilon \mathrm{C}$.

It is obvious from above equation that

$\|\mathrm{Ax}-\mathrm{Ay}\| \leq \frac{1}{\alpha}\|\mathrm{x}-\mathrm{y}\|$.

Lemma 2.4 [3] Let $\mathrm{C}$ be a nonempty closed convex subset of a 2-uniformly smooth Banach space E. Let $\alpha>0$ and let $\mathrm{A}: \mathrm{C} \rightarrow \mathrm{E}$ be an $\alpha$-inverse strongly accretive operator. If $0<\lambda \leq \frac{\alpha}{K^{2}}$, then $\mathrm{I}-\lambda \mathrm{A}$ is a nonexpansive mapping of $\mathrm{C}$ into $\mathrm{E}$, where $\mathrm{K}$ is the 2-uniformly smoothness constant of $\mathrm{E}$.

Lemma 2.5 [9] Let $\mathrm{C}$ be a nonempty closed convex subset of a uniformly convex Banach space with a frechet differentiable norm. Let $\left\{\mathrm{T}_{1}, \mathrm{~T}_{2}, \ldots \ldots\right\}$ be a sequence of nonexpansive mappings of $\mathrm{C}$ into itself with $\bigcap_{n=1}^{\infty} F\left(T_{n}\right) \neq \varphi \quad$. Let $\quad \mathrm{x} \quad \varepsilon \quad \mathrm{C}$ and $\mathrm{S}_{\mathrm{n}}=\mathrm{T}_{\mathrm{n}} \mathrm{T}_{\mathrm{n}-1} \ldots \ldots \ldots \mathrm{T}_{1}$ for all $\mathrm{n} \geq 1$. Then the set $\bigcap_{n=1}^{\infty} c \bar{o}\left\{S_{m} x: m \geq n\right\} \bigcap \bigcap_{n=1}^{\infty} F\left(T_{n}\right)$ consists of atmost one point, where $c \bar{o} \mathrm{D}$ is the closure of the convex hull of D.

Lemma 2.6 [2] Let $\mathrm{q}$ be a given real number with $1<\mathrm{q} \leq 2$ and let $\mathrm{E}$ be a q-uniformly smooth Banach space. Then,

$\|\mathrm{x}+\mathrm{y}\|^{\mathrm{q}} \leq\|\mathrm{x}\|^{\mathrm{q}}+\mathrm{q}<\mathrm{y}, \mathrm{J}_{\mathrm{q}}(\mathrm{x})>+2\|\mathrm{Ky}\|^{2}$, for all $\mathrm{x}, \mathrm{y} \varepsilon \mathrm{E}$, where $\mathrm{J}_{\mathrm{q}}$ is the generalized duality mapping of $\mathrm{E}$ and $\mathrm{K}$ is the q-uniformly smoothness constant of $\mathrm{E}$.

Theorem 2.7 [1] Let $\mathrm{D}$ be a nonempty bounded closed convex subset of a uniformly convex Banach space $\mathrm{E}$ and let $\mathrm{T}$ be a nonexpansive mapping of $\mathrm{D}$ into itself. If $\left\{\mathrm{u}_{\mathrm{j}}\right\}$ is a sequence of $\mathrm{D}$ such that $\mathrm{u}_{\mathrm{j}} \rightarrow \mathrm{u}_{0}$ and let $\lim _{j \rightarrow \infty}\left\|u_{j}-T u_{j}\right\|=0$, then $\mathrm{u}_{0}$ is a fixed point of $\mathrm{T}$.

\section{Main Result}

In this section, we shall prove our main result.

Theorem 3.1 Let $\mathrm{E}$ be a uniformly convex and 2-uniformly smooth Banach space with best smooth constant $\mathrm{K}$ and $\mathrm{C}$ be a nonempty closed convex subset of $\mathrm{E}$. Let $\mathrm{Q}_{\mathrm{C}}$ be a sunny nonexpansive retraction from $\mathrm{E}$ onto $\mathrm{C}, \alpha>$ 0 and $\mathrm{A}$ be $\alpha$-inverse strongly accretive operator of $\mathrm{C}$ into $\mathrm{E}$. Let $\mathrm{S}(\mathrm{C}, \mathrm{A}) \neq \varphi$ and the sequence $\left\{\mathrm{x}_{\mathrm{n}}\right\}$ be generated by

$\mathrm{y}_{\mathrm{n}}=\mathrm{Q}_{\mathrm{C}}\left(\mathrm{x}_{\mathrm{n}}-\lambda_{\mathrm{n}} \mathrm{Ax} \mathrm{x}_{\mathrm{n}}\right)$

$\mathrm{x}_{\mathrm{n}+1}=\alpha_{\mathrm{n}} \mathrm{x}_{\mathrm{n}}+\left(1-\alpha_{\mathrm{n}}\right) \mathrm{Q}_{\mathrm{C}}\left(\mathrm{y}_{\mathrm{n}}-\lambda_{\mathrm{n}} \mathrm{A} \mathrm{y}_{\mathrm{n}}\right), \mathrm{x}_{1} \in \mathrm{C}, \mathrm{n}=1,2,3, \ldots \ldots \ldots \ldots$,

where $\left\{\lambda_{n}\right\}$ is a sequence of positive real numbers satisfying $\lambda_{n} \leq \alpha$ and $\lambda_{n} \in\left[a, \alpha / K^{2}\right]$ for some a $>0$ and let $\alpha_{n} \in$ $[b, c]$, where $0<b<c<1$, then $\left\{x_{n}\right\}$ converges weakly to some element $\mathrm{z}$ of $\mathrm{S}(\mathrm{C}, \mathrm{A})$.

Proof. Let $z_{n}=Q_{C}\left(y_{n}-\lambda_{n} A y_{n}\right)$ for $n=1,2$, Let $\mathrm{u} \in \mathrm{S}(\mathrm{C}, \mathrm{A})$. Now,

$\left\|y_{n}-u\right\| \leq\left\|Q_{C}\left(x_{n}-\lambda_{n} A x_{n}\right)-Q_{C}\left(u-\lambda_{n} A u\right)\right\|$

$\leq\left\|\mathrm{x}_{\mathrm{n}}-\mathrm{u}\right\|$

Also,

$\left\|z_{n}-u\right\| \leq\left\|Q_{C}\left(y_{n}-\lambda_{n} A y_{n}\right)-Q_{C}\left(u-\lambda_{n} A u\right)\right\|$

$\leq\left\|\mathrm{y}_{\mathrm{n}}-\mathrm{u}\right\| \leq\left\|\mathrm{x}_{\mathrm{n}}-\mathrm{u}\right\|$

Now, for every $n=1,2, \ldots \ldots \ldots \ldots$,

$\left\|\mathrm{x}_{\mathrm{n}+1}-\mathrm{u}\right\|=\left\|\alpha_{\mathrm{n}}\left(\mathrm{x}_{\mathrm{n}}-\mathrm{u}\right)+\left(1-\alpha_{\mathrm{n}}\right)\left(\mathrm{z}_{\mathrm{n}}-\mathrm{u}\right)\right\|$

$\leq \alpha_{\mathrm{n}}\left\|\mathrm{x}_{\mathrm{n}}-\mathrm{u}\right\|+\left(1-\alpha_{\mathrm{n}}\right)\left\|\mathrm{z}_{\mathrm{n}}-\mathrm{u}\right\|$ 
Using (3.2) and (3.3), $\left\|\mathrm{x}_{\mathrm{n}+1}-\mathrm{u}\right\| \leq\left\|\mathrm{x}_{\mathrm{n}}-\mathrm{u}\right\|$

(3.4) shows that $\left\{\left\|x_{n}-u\right\|\right\}$ is non-increasing sequence.

So, there exists $\lim _{n \rightarrow \infty}\left\|x_{n}-u\right\|$ and hence $\left\{x_{n}\right\}$ is a bounded sequence . (3.2) and (3.3) shows that $\left\{y_{n}\right\},\{$ $\left.A x_{n}\right\}$ and $\left\{z_{n}\right\}$ are also bounded .

Next, we shall show that $\lim _{n \rightarrow \infty}\left\|x_{n}-y_{n}\right\|=0$. Conversely, let $\lim _{n \rightarrow \infty}\left\|x_{n}-y_{n}\right\| \neq 0$. Then there exists $\in>0$ and a subsequence $\left\{x_{n_{i}}-y_{n_{i}}\right\}$ of $\left\{\mathrm{x}_{\mathrm{n}}-\mathrm{y}_{\mathrm{n}}\right\}$ such that $\left\|x_{n_{i}}-y_{n_{i}}\right\| \geq \in$ for each $\mathrm{i}=1,2$ Since $\mathrm{E}$ is uniformly convex, so the function $\|.\|^{2}$ is uniformly convex on bounded convex subset $\mathrm{B}\left(0,\left\|\mathrm{x}_{1}-\mathrm{u}\right\|\right)$, where $\mathrm{B}\left(0, \| \mathrm{x}_{1}\right.$ $\mathrm{u} \|)=\left\{\mathrm{x} \in \mathrm{E}:\|\mathrm{x}\| \leq\left\|\mathrm{x}_{1}-\mathrm{u}\right\|\right\}$.

So, for any $\in$, there exists $\delta>0$ such that $\|\mathrm{x}-\mathrm{y}\| \geq \in$ implies

$\|\lambda x+(1-\lambda) y\|^{2}$

$\leq \lambda\|x\|^{2}+(1-\lambda)\|y\|^{2}-\lambda(1-\lambda) \delta$,

where $\mathrm{x}, \mathrm{y} \in \mathrm{B}\left(0,\left\|\mathrm{x}_{1}-\mathrm{u}\right\|\right), \lambda \in(0,1)$. So for $\mathrm{i}=1,2, \ldots \ldots \ldots$,

$\left\|x_{n_{i}+1}-\mathrm{u}\right\|^{2}=\left\|\alpha_{n_{i}}\left(x_{n_{i}}-\mathrm{u}\right)+\left(1-\alpha_{n_{i}}\right)\left(z_{n_{i}}-\mathrm{u}\right)\right\|^{2}$

$\leq \alpha_{n_{i}}\left\|x_{n_{i}}-\mathrm{u}\right\|^{2}+\left(1-\alpha_{n_{i}}\right)\left\|y_{n_{i}}-\mathrm{u}\right\|^{2}-\alpha_{n_{i}}\left(1-\alpha_{n_{i}}\right) \delta$

$\leq \alpha_{n_{i}}\left\|x_{n_{i}}-\mathrm{u}\right\|^{2}+\left(1-\alpha_{n_{i}}\right)\left\|x_{n_{i}}-\mathrm{u}\right\|^{2}-\alpha_{n_{i}}\left(1-\alpha_{n_{i}}\right) \delta$

$\leq\left\|x_{n_{i}}-\mathrm{u}\right\|^{2}-\alpha_{n_{i}}\left(1-\alpha_{n_{i}}\right) \delta$

Therefore,

$0<\mathrm{b}(1-\mathrm{c}) \delta \leq \alpha_{n_{i}}\left(1-\alpha_{n_{i}}\right) \delta \leq\left\|x_{n_{i}}-\mathrm{u}\right\|^{2}-\left\|x_{n_{i}+1}-\mathrm{u}\right\|^{2}$

Since right hand side of inequality (3.5) converges to 0 , so we get a contradiction.

Hence, $\lim _{\mathrm{n} \rightarrow \infty}\left\|\mathrm{x}_{\mathrm{n}}-\mathrm{y}_{\mathrm{n}}\right\|=0$

Now, since $\left\{\mathrm{x}_{\mathrm{n}}\right\}$ is bounded, so there exists a subsequence $\left\{x_{n_{i}}\right\}$ of $\left\{\mathrm{x}_{\mathrm{n}}\right\}$ that weakly converges to $\mathrm{z}$. Also $\lambda_{n_{i}} \epsilon$ $\left[\mathrm{a}, \alpha / \mathrm{K}^{2}\right]$, so $\left\{\lambda_{n_{i}}\right\}$ is bounded. Hence, there exists a subsequence $\left\{\lambda_{n_{i_{j}}}\right\}$ of $\left\{\lambda_{n_{i}}\right\}$ that weakly converges to $\lambda_{0} \in\left[\mathrm{a}, \alpha / \mathrm{K}^{2}\right]$. Without loss of generality assume that $\lambda_{n_{i}} \rightarrow \lambda_{0}$. Since $\mathrm{Q}_{\mathrm{C}}$ is nonexpansive, so

$y_{n_{i}}=\mathrm{Q}_{\mathrm{C}}\left(x_{n_{i}}-\lambda_{n_{i}} A x_{n_{i}}\right)$ implies that

$\left\|Q_{C}\left(x_{n_{i}}-\lambda_{0} A x_{n_{i}}\right)-x_{n_{i}}\right\|$

$\leq\left\|Q_{C}\left(x_{n_{i}}-\lambda_{0} A x_{n_{i}}\right)-y_{n_{i}}\right\|+\left\|y_{n_{i}}-x_{n_{i}}\right\|$

$=\left\|Q_{C}\left(x_{n_{i}}-\lambda_{0} A x_{n_{i}}\right)-Q_{C}\left(x_{n_{i}}-\lambda_{n_{i}} A x_{n_{i}}\right)\right\|+\left\|y_{n_{i}}-x_{n_{i}}\right\|$

$\leq\left|\lambda_{0}-\lambda_{n_{i}}\right||| A x_{n_{i}}\|+\| y_{n_{i}}-x_{n_{i}} \|$

$\leq M\left|\lambda_{0}-\lambda_{n_{i}}\right|+\| y_{n_{i}}-x_{n_{i}}||$

where $\mathrm{M}=\sup \left\{\left\|\mathrm{Ax}_{\mathrm{n}}\right\|: \mathrm{n}=1,2,3\right.$ . . Equation (3.6), (3.7) and convergence of $\left\{\lambda_{n_{i}}\right\}$ implies that

$\lim _{i \rightarrow \infty}\left\|Q_{C}\left(I-\lambda_{0} A\right) x_{n_{i}}-x_{n_{i}}\right\|=0$

Also, $Q_{C}\left(I-\lambda_{0} A\right)$ is nonexpansive, so (3.8), lemma 2.3 and theorem 2.7 implies $\mathrm{z} \& \mathrm{~F}\left(\mathrm{Q}_{\mathrm{C}}\left(\mathrm{I}-\lambda_{0} \mathrm{~A}\right)\right)=\mathrm{S}(\mathrm{C}, \mathrm{A})$.

Lastly, we shall prove that $\left\{x_{n}\right\}$ is convergent to some element of $S(C, A)$. Let

$\mathrm{T}_{\mathrm{n}}=\alpha_{\mathrm{n}} \mathrm{I}+\left(1-\alpha_{\mathrm{n}}\right) \mathrm{Q}_{\mathrm{C}}\left(\mathrm{I}-\lambda_{\mathrm{n}} \mathrm{A}\right)$, for $\mathrm{n}=1,2$

Then, $\mathrm{x}_{\mathrm{n}+1}=\mathrm{T}_{\mathrm{n}} \mathrm{T}_{\mathrm{n}+1} \ldots \ldots \ldots \ldots \ldots \ldots \mathrm{T}_{1} \mathrm{x}$ and $\mathrm{z} \varepsilon \bigcap_{\mathrm{n}=1}^{\infty} \mathrm{c} \overline{\mathrm{O}}\left\{\mathrm{x}_{\mathrm{m}}: \mathrm{m} \geq \mathrm{n}\right\}$. Also from lemma 2.4, $\mathrm{T}_{\mathrm{n}}$ is nonexpansive mapping of $\mathrm{C}$ into itself. And from lemma 2.3, we have, 


$$
\bigcap_{n=1}^{\infty} F\left(T_{n}\right)=\bigcap_{n=1}^{\infty} F\left(Q_{C}\left(I-\lambda_{n} A\right)\right)=S(C, A) .
$$

Using theorem (2.5), we obtain

$$
\bigcap_{\mathrm{n}=1}^{\infty} \mathrm{co}\left\{\mathrm{x}_{\mathrm{m}}: \mathrm{m} \geq \mathrm{n}\right\} \bigcap \mathrm{S}(\mathrm{C}, \mathrm{A})=\{\mathrm{z}\}
$$

Hence, the sequence $\left\{x_{n}\right\}$ is weakly convergent to some element of $S(C, A)$.

\section{Application}

Using our main result, we shall prove a result for strongly accretive operator.

Let $\mathrm{C}$ be a subset of a smooth Banach space $\mathrm{E}$. Let $\alpha>0$. An operator $\mathrm{A}$ of $\mathrm{C}$ into $\mathrm{E}$ is said to be $\alpha$-strongly accretive if

$<\mathrm{Ax}-\mathrm{Ay}, \mathrm{J}(\mathrm{x}-\mathrm{y})>\geq \alpha\|\mathrm{x}-\mathrm{y}\|^{2}$ for all $\mathrm{x}, \mathrm{y} \varepsilon \mathrm{C}$.

Let $\beta>0$. An operator $A$ of $C$ into $E$ is said to be $\beta$-Lipschitz continuous if $\|A x-A y\| \leq \beta\|x-y\|$, for all $x, y \varepsilon C$.

Theorem 4.1 Let $\mathrm{E}$ be a uniformly convex and 2-uniformly smooth Banach space with best smooth constant $\mathrm{K}$ and $\mathrm{C}$ be a nonempty closed convex subset of $\mathrm{E}$. Let $\mathrm{Q}_{\mathrm{C}}$ be be a sunny nonexpansive retraction from $\mathrm{E}$ onto $\mathrm{C}, \alpha$ $>0, \beta>0$ and A be $\alpha$-strongly accretive operator and $\beta$-Lipschitz continuous operator of C into E. Let $\mathrm{S}(\mathrm{C}, \mathrm{A})$ $\neq \varphi$ and the sequence $\left\{x_{n}\right\}$ be generated by

$\mathrm{y}_{\mathrm{n}}=\mathrm{Q}_{\mathrm{C}}\left(\mathrm{x}_{\mathrm{n}}-\lambda_{\mathrm{n}} \mathrm{Ax} \mathrm{x}_{\mathrm{n}}\right)$,

$\mathrm{x}_{\mathrm{n}+1}=\alpha_{\mathrm{n}} \mathrm{x}_{\mathrm{n}}+\left(1-\alpha_{\mathrm{n}}\right) \mathrm{Q}_{\mathrm{C}}\left(\mathrm{y}_{\mathrm{n}}-\lambda_{\mathrm{n}} \mathrm{A} \mathrm{y}_{\mathrm{n}}\right), \mathrm{x}_{1} \in \mathrm{C}, \mathrm{n}=1,2,3$,

where $\left\{\lambda_{n}\right\}$ is a sequence of positive real numbers satisfying $0 \leq \lambda_{n} \leq 1$ and $\lambda_{n} \in\left[a, \alpha / K^{2}\right]$ for some a $>0$ and let $\alpha_{\mathrm{n}} \in[\mathrm{b}, \mathrm{c}]$, where $0<\mathrm{b}<\mathrm{c}<1$, then $\left\{\mathrm{x}_{\mathrm{n}}\right\}$ converges weakly to a unique element $\mathrm{z}$ of $\mathrm{S}(\mathrm{C}, \mathrm{A})$.

Proof. Since $\mathrm{A}$ is an $\alpha$-strongly accretive and $\beta$-Lipschitz continuous operator of $\mathrm{C}$ into $\mathrm{E}$, we have

$<\mathrm{Ax}-\mathrm{Ay}, \mathrm{J}(\mathrm{x}-\mathrm{y})>\geq \alpha\|\mathrm{x}-\mathrm{y}\|^{2} \geq \frac{\alpha}{\beta^{2}}\|\mathrm{Ax}-\mathrm{Ay}\|^{2}$, for all $\mathrm{x}, \mathrm{y} \varepsilon \mathrm{C}$.

So $A$ is $\frac{\alpha}{\beta^{2}}$ - inverse strongly accretive. Since $A$ is strongly accretive and $S(C, A) \neq \varphi$, so the set $S(C, A)$ consists of one point $\mathrm{z}$. Using theorem $3.1,\left\{\mathrm{x}_{\mathrm{n}}\right\}$ converges weakly to a unique element $\mathrm{z}$ of $\mathrm{S}(\mathrm{C}, \mathrm{A})$.

\section{References}

[1]. F. E. Browder, Nonlinear operators and nonlinear equations of evoluation in Banach spaces, Nonlinear Functional Analsis (proc.Sympos.pure Math., vol. XVIII, Part 2,Chicago, III, 1968), American Mathematical Society, Rhode Island, 1976 , pp. 1-308.

[2]. H. K. Xu, Inequalities in Banach Spaces with applications, Nonlinear Analysis, 16(1991), no.12, $1127-1138$.

[3]. K. Aoyama, H. Iiduka, W. Takashi, Weak convergence of an iterative sequence for accretive operators in Banach spaces, Fixed point theory and applications, vol 2006, p 1-13.

[4]. K. Ball, A. Carlen and E. H. Lieb, Sharp uniform convexity and smoothness inequalities for trace norms, Inventiones Mathematicae, 115(1994), no. 3, 463-482.

[5]. N. Nadezhkina and W. Takahashi, Weak convergence theorem by an extragradient method for nonexpansive mappings and monotone Mappings, Journal of Optimization Theory and Applications, vol. 128, pp. 191-201, 2006.

[6]. R. E. Bruck Jr., Nonexpansive retracts of Banach spaces, Bulletin of the American mathematical society, 76(1970), 384-386.

[7]. S. Kitahara and W. Takahashi, Image recovery by convex combinations of sunny nonexpansive retractions, Topological methods in Nonlinear analysis, 2(1993), no. 2, 333-342.

[8]. S. Reich, Asymptotic behavior of contractions in Banach spaces, Journal of Mathematical Analysis and Applications, 44(1973), no. $1,57-70$.

[9]. S. Reich, Weak convergence theorems for nonexpansive mappings in Banach spaces, Journal of Mathematical Analysis and Applications, 67(1979), no. 2, 274-276.

[10]. W. Takahashi, Nonlinear functional analysis, Yokohama publisher, Yokohama, Japan, 2000.

[11]. Y. Takahashi, K. Hashimoto and M. Kato, On sharp uniform convexity, smoothness and strong type, cotype inequality, Journal of Nonlinear and Convex Analysis, 3(2002), no. 2, 267-281. 